\title{
ANALISIS KINERJA PEGAWAI KANTOR DESA INDRASARI KECAMATAN MARTAPURA KABUPATEN BANJAR
}

\author{
Widiati \\ FIA, Universitas Achmad Yani Banjarmasin \\ Email : widiawatiw61@gmail.com
}

\begin{abstract}
The purpose of this study is to determine the performance of Indrasari Village office employees by using the theory of performance measurement. The research method-using a qualitative approach with descriptive type, primary and secondary data sources, data collection techniques using literature, observation, interviews, and documentation. The data analysis technique uses data reduction, data presentation, and verification/decision making.

The results of the study indicate that there is still overlapping work that occurs, it can be seen that several employees who should be working are still relaxing, coupled with the main tasks that should be owned by one Section Head/Kasi is actually carried out by another Kasi, the ability to initiate employees is still not evenly distributed, often destination address error. It can be concluded that the performance of the Indrasari Village office employees when analyzed using existing theories, the results are not fully optimal.
\end{abstract}

Keywords: Performance, Employees, Village Office.

\section{PENDAHULUAN}

Kinerja pemerintahan desa merupakan bentuk kegiatan yang dilakukan oleh pemerintahan dalam memberikan pelayanan terhadap masyarakat setempat, hal ini merupakan bentuk sebuah pengabdian yang dilakukan oleh pemerintahan desa, mengenai bentuk pelayanan yang diberikan terdapat pelayanan administrasi dan non administrasi, kegiatan yang dilakukan oleh pemerintahan desa merupakan bentuk pelayanan publik yang harus dilakukan oleh pemerintahan desa.

Dalam Undang-Undang Dasar Republik Indonesia 1945 pasal 22D ayat (3) mengamanatkan bahwa pemerintah daerah berwenang untuk mengatur dan mengurus sendiri urusan pemerintahan menurut asas otonomi daerah. Hal tersebut diarahkan untuk mempercepat terwujudnya kesejateraan masyarakat daerah melalui peningkatan pelayanan, pemberdayaan, dan peran serta masyarakat, serta peningkatan daya saing daerah dengan memperhatikan prinsip demokrasi, pemerataan, keadilan, keistimewaan dan kekhususan suatu daerah dalam Negara Kesatuan Republik Indonesia.
Widodo (2001:121) mempunyai anggapan bahwa kinerja aparat pemerintah masih relatif rendah dan belum sepenuhnya bisa memenuhi harapan dan pilihan publik, ketika melaksanakan tugas pokok, fungsi, kewenangan, dan tanggung jawab, terutama dalam menyelenggarakan pemerintahan, pembangunan dan pelayanan masyarakat. Melihat pentingnya peranan aparat, pemerintah tersebut secara tidak langsung lancar atau tidaknya pembangunan di dalam negeri ini ditentukan oleh bagaimana aparat pemerintah tersebut menjalankan tugas pokok, fungsi, dan tanggung jawabnya.

Penyelenggaraan suatu desa atau organisasi merupakan hal yang tidak mudah dilakukan karena menyangkut kepentingan umum atau orang banyak, penyelenggaraan harus dilengkapi dengan suatu perangkat yang dianggap mampu untuk mencapai sebuah tujuan, yaitu seperti sumber daya manusia yang terstuktur.

Setiap instansi memerlukan sumber daya manusia untuk mencapai tujuannya, sumber daya diperlukan untuk menciptakan daya, gerakan, aktivitas, kegiatan dan tindakan 
dalam sebuah organisasi, instansi atau perusahaan. Sumber daya tersebut berupa sumber daya finensial, sumber daya alam, sumber daya teknologi, sumber daya manusia dan sumber daya ilmu pengetahuan, diantara semua sumber daya tersebut yang paling penting adalah sumber daya manusia. Sumber daya manusia merupakan sumber daya yang dipergunakan untuk menggerakkan dan mendayagunakan sumber daya lainnya untuk mencapai suatu tujuan.

Pegawai sebagai sumber daya manusia merupakan aset terpenting yang dimiliki oleh suatu instansi juga suatu lembaga, oleh karena itu pengelolaan perlu dilakukan secara efektif dan efisien. Tiap instansi yang memberikan pelayanan (Service) baik berupa produk barang atau jasa harus memperhatikan kualitas pelayanan sehingga seluruh pegawai dituntut untuk memiliki kompetensi dalam menjalankan tugas dan tanggung jawab yang telah dibebankan kepadanya. Pada kondisi seperti ini, maka menejemen sumber daya manusia mempunyai peranan yang sangat penting dalam memanfaatkan dan mengembangkan sumber daya yang dimiliki, sehingga suatu instansi/organisasi dapat memberikan pelayanan publik seiring dengan perubahan tuntutan masyarakat (publik).

Setiap kantor atau sebuah instansi akan selalu berusaha untuk meningkatkan kinerja pegawai dengan harapan yang menjadi tujuan sebuah instansi akan tercapai. Berbagai cara yang akan ditempuh oleh instansi dalam meningkatkan kinerja pegawainya, misalnya dengan memperhatikan disiplin kerja pegawai, memperhatikan kepuasan kerja pegawai dan memberikan kompensasi yang sesuai kepada pegawai tersebut. Agar kepuasan kerja pegawai selalu konsisten maka setidaktidaknya instansi selalu memperhatikan lingkungan dimana pegawai melaksanakan tugasnya yang berhubungan dengan rekan kerja, pimpinan, suasana kerja dan hal-hal lain yang dapat mempengaruhi kemampuan seorang pegawai dalam menjalankan perkerjaanya.
Suatu organisasi pemerintah besar maupun kecil dalam mencapai tujuan yang telah ditetapkan harus melalui kegiatankegiatan yang telah digerakkan oleh orang atau sekelompok orang yang aktif berperan sebagai pelaku, dengan lain tercapainya tujuan organisasi hanya dimungkinkan karena adanya upaya yang dilakukan oleh orang dalam organisasi tersebut.

Kinerja organisasi akan sangat ditentukan oleh unsur pegawainya karena itu dalam mengukur kinerja suatu organisasi sebaiknya diukur dalam tampilan kinerja dari pegawainya. Kinerja yang diungkapkan dari berbagai pakar, diantaranya. kinerja adalah hasil kerja secara kualitas dan kuantitas yang dicapai oleh seorang pegawai dalam melaksanakan tugasnya sesuai dengan tanggung jawab yang diberikan kepadanya.

Menurut Carlzon dalam Sadu Wasistino (2003:16) mengatakan, bahwa abad ke-21 sebagai "abad pelanggan", dalam arti para pengguna jasa atau pelanggan ditempatkan pada tempat yang sangat tinggi atau terhormat. Dari pemikiran tersebut, dikaitkan dengan kondisi nyata sementara pegawai kantor Desa Indrasari, Kecamatan Martapura, Kabupaten Banjar sebagai tempat penelitian yang direncanakan ini, menurut pengamatan awal penelitian, menunjukkan bahwa

kemampuan pegawai pada kantor desa Indrasari dalam pelaksanaan tugas terutama dalam menyiapkan bahan dan informasi yang dibutuhkan untuk kepentingan masyarakat, hasilnya masih minim atau belum terlaksana secara optimal.

Dilihat dari observasi bahwa pelaksanaan tugas-tugas administrasi yang tidak terlaksana dengan baik misalnya berkas yang telah dikerjakan oleh pegawai (atas permintaan masyarakat), masih ada terjadi kesalahan pengetikan, baik administrasi umum, administrasi penduduk, maupun administrasi lainnya. Permasalahan lainnya mengenai penyelesaian perkerjaan yang memakan waktu cukup lama serta kurangnya inisiatif pegawai dalam berkerja, terlihat bahwa pegawai masih belum 
menyadari/memahami dengan perkerjaan yang menumpuk, mendesak serta penting, selain itu mengenai kurangnya kerjasama antar pegawai terlihat bahwa dalam penyelesaian perkerjaan masih saling melemparkan tanggung jawab, dan juga pada kantor desa tersebut sistem penyampaian dan penerimaan informasi (dari kecamatan, kabupaten, provinsi) masih dilakukan secara manual atau belum digunakannya sistem online.

Isu-isu masalah yang terjadi kurangnya pelayanan dalam memberikan pelayanan administrasi penduduk dilihat dari aspek kualitas seperti pembuatan: 1) surat pengantar Kartu Tanda Penduduk (KTP ), 2) surat pengantar Kartu Keluarga (KK), 3) surat pengantar surat nikah, 4) surat pengantar akte kelahiran, 5) surat pindah, 6) surat keterangan tidak mampu, 7) surat izin usaha, kapasitas yang masih rendah merupakan bagian dari permasalahan yang ditunjukkan di lapangan, dan juga kemampuan berkomunikasi pegawai yang belum optimal, serta banyaknya pegawai yang sering datang terlambat untuk berkerja, disimpulkan bahwa masih belum optimalnya aspek pelayanan yang diberikan oleh pemerintahan desa.

\section{TINJAUAN PUSTAKA}

\section{Konsep Kinerja}

Menurut Kamus Besar Bahasa Indonesia, kinerja yaitu suatu yang dicapai, prestasi yang diperlihatkan, serta kemampuan kerja. Kinerja adalah istilah yang populer di dalam manajemen, yang mana istilah kinerja didefinisikan dengan istilah hasil kerja, prestasi kerja atau performance.

Pengertian kinerja menurut Lembaga Administrasi Negara Republik Indonesia (LAN-RI) yang dikutip oleh pasolong (2013:175-176) dalam bukunya "Teori Administrasi Publik" adalah sebagai berikut: "Kinerja adalah gambaran umum mengenai tingkat pencapaian pelaksanaan suatu kegiatan, program, kebijaksanaan dalam mewujudkan sasaran, tujuan, misi dan visi organisasi”.

Wibowo dalam M. Ma'ruf Abdullah, (2014:3) menyebutkan bahwa kinerja itu berasal dari kata performance yang berarti hasil pekerjaan atau prestasi kerja. Namun perlu pula dipahami bahwa kinerja itu bukan sekedar hasil pekerjaan atau prestasi kerja, tetapi juga mencakup bagaimana proses pekerjaan itu berlangsung.

Amstrong dan Baron dalam Prof. Dr. H. M. Ma'ruf Abdullah, SH. MM (2014:3) mengatakan bahwa kinerja merupakan hasil pekerjaan yang mempunyai hubungan kuat dengan tujuan strategi organisasi, kepuasan konsumen dan memberikan kontribusi ekonomi.

Abdullah dalam PM. Ma'ruf Abdullah, (2014:3) dilihat dari asal katanya, kinerja itu adalah terjemahan dari performance yang berarti hasil kerja atau prestasi kerja. Dan dalam pengertian yang simpel kinerja adalah hasil dari pekerjaan organisasi, yang dikerjakan oleh karyawan dengan sebaikbaiknya sesuai dengan petunjuk (manual), arahan yng diberikan oleh pimpinan (manajer), kompetensi dan kemampuan karyawan mengembangkan nalarnya dalam bekerja.

Wirawan dalam M. Ma'ruf Abdullah, (2014:3) kinerja merupakan singkatan dari kinetika energi kerja yang padanannya dalam bahasa Inggris adalah performance. Kinerja adalah keluaran yang dihasilkan oleh fungsifungsi atau indikator-indikator suatu pekerjaan atau suatu profesi dalam waktu tertentu.

Menurut masram (2017:147) faktor yang mempengaruhi kinerja terdiri dari:

1) Efektifitas dan efisiensi, bila suatu tujuan tertentu akhirnya bisa di capai maka dikatakan bahwa kegiatan tersebut efektif dan bila sesuai target waktunya maka dikatan efisien.

2) Otoritas (wewenang) adalah sifat dari suatu komunikasi atau pemerintah dalam suatu organisasi formal untuk melakukan suatu kerja dengan kontribusinya.

3) Disiplin, adalah taat kepada hukum dan peraturan yang berlaku.

4) Inisiatif adalah berkaitan dengan daya fikir dan kreatifitas dalam membentuk ide untuk merencanakan sesuatu yang berkaitan dengan tujuan organisasi. 
Syukuri 2002:8 (dalam Abdul Kadir 2015:137) menjelaskan bahwa untuk mendapatkan kinerja yang optimal di perlukan 4 (empat) persyaratan, yaitu :

1. Kapasitas sumber daya manusia yang memadai, kemampuan pengetahuan, keterampilan dan pengalaman serta didukung oleh sikap mental dan moral, loyalitas dan dedikasi dari eksekutif akan sangat mendukung bagi terwujudnya kinerja daerah yang optimal;

2. Rekrutmen yang baik, untuk mendapatkan pegawai yang memenuhi syarat (quaified) diperlukan suatu mekanisme dan proses rekrutmen yang tertata dengan baik dan benar;

3. Pembinaan yang memadai, untuk menngkatkan kinerja maka perlunya upaya pembinaan untuk meningkatkan kapasitasnya secara terencana dan berkeanjutan; dan

4. Pengawasan masyarakat, baik oleh lembaga perwakilan rakyat, maupun media massa dan masyarakat secara langsung perlu dilaksanakan dan ditingkatkan secara terus-menerus.

Moeheriono dalam Prof. Dr. H. M. Ma'ruf Abdullah, SH. MM (2014:3) kinerja atau performance merupakan gambaran mengenai tingkat pencapaian pelaksanaan suatu program kegiatan atau kebijakan dalam mewujudkan sasaran, tujuan, visi, dan misi organisasi yang dituangkan melalui perencanaan strategis suatu organisasi.

\section{Pengukuran Kinerja}

Untuk mengetahui pengukuran pada suatu kinerja, terdapat indikator kinerja yang harus diketahui lebih dulu, yaitu sebagai berikut :

Menurut bpkp dalam Abdullah, 2014:145 Indikator kinerja adalah ukuran kuantitatif dan kualitataif yang menggambarkan tingkat pencapaian sesuatu sasaran atau tujuan yang telah ditetapkan. Sementara itu menurut Lohman (2003) dalam Abdullah (2014:145) Indikator kinerja adalah suatu variabel yang digunakan untuk mengekspresikan secara kuantitatif efektivitas dan efisiensi proses atau operasi dengan berpedoman pada target-target dan tujuan organisasi. Dalam pandangan lain, Moeheriono (2012:108) mendefinisikan indikator kinerja sebagai berikut :

a. Indikator kinerja adalah nilai atau karakteristik tertentu yang digunakan untuk mengukur output atau outcome suatu kegiatan.

b. Indikator kinerja adalah alat ukur yang dipergunakan untuk menentukan derajat keberhasilan suatu organisasi dalam mencapai tujuannya.

Menurut Surya Dharma (2012:83), mengemukakan bahwa indikator kinerja sebagai berikut :

a) Konsisten;

b) Tempat;

c) Menantang;

d) Dapat diukur;

e) Dapat dicapai;

f) Disepakati;

g) Dihubungkan dengan waktu;

h) Berorientasikan kerja kelompok.

Berdasarkan pengertian diatas, maka dapat disimpulkan bahwa indikator kinerja merupakan suatu variabel yang dipergunakan untuk mengukur atau menilai tingkat pencapaian sesuatu sasaran yang telah ditetapkan dan menentukan derajat keberhasilan suatu instansi/organisasi dalam mencapai tujuannya.

Dr. Meithiana Indrasari, S.T., M.M. (2017: 57-58) mengatakan konsep yang dapat dijadikan sebagai acuan guna mengukur dan menilai kinerja pegawai, yaitu;

1. Faktor kualitas kerja, yang dapat dilihat dari segi ketelitian dan kerapian bekerja, kecepatan penyelesaian pekerjaan, keterampilan dan kecakapan kerja.

2. Faktor kuantitas kerja, diukur dari kemampuan secara kuantitatif di dalam mencapai target atau hasil kerja atas pekerjaan-pekerjaan baru.

3. Faktor pengetahuan, meninjau kemampuan pegawai dalam memahami hal-hal yang berkaitan dengan tugas yang mereka lakukan. 
Aspek-aspek yang dapat dijadikan sebagai ukuran kinerja terdapat lima aspek, menurut T.R Mitchell (1978:34) dalam Sedarmayanti (2001:51), ia menyatakan bahwa kelima aspek kinerja, yaitu :

\section{Kualitas Kerja (Quality of work)}

Dengan menilai kualitas perkerjaan ini dapat terlihat sejauh mana kontribusi yang dilakukan oleh pegawai terhadap organisasi, yaitu dilihat dari hasil kerja dan ketelitian serta kecermatan dalam pelaksanaan dan penyelesaian tugas oleh pegawai, tingkat komitmen terhadap pelaksanaan dan penyelesaian tugas, perbaikan serta peningkatan mutu hasil kerja. Penilaian ini juga agar para pegawai mengetahui bilamana mereka memenuhi standar kualitas perkerjaannya. Faktor-Faktor Yang Mempengaruhi Kualitas Kerja, Menurut Swasono dan Sulistyaningsih (1993) dalam Sudaryanti (2010:122) mengidentifikasi empat kondisi yang mempengaruhi kualitas kerja, yaitu:

a. Security (keamanan) meliputi kesehatan, keamanan kerja dan pertumbuhannya.

b. Equity (kesamarataan) meliputi kesamaan pendapat pada jenis pekerjaan yang serupa baik didalam organisasi itu sendiri maupun didalam organisasi lain, kesamarataan, kesejahteraan, kondisi kerja dan lain-lain.

c. Pengembangan individu melalui peningkatan kemampuan, peningkatan kesamarataan, kesejahteraan dan lain-lain.

d. Demokrasi, adanya kesempatan berpartisipasi dalam pengambilan keputusan.

\section{Ketepatan waktu (Prompness)}

Aspek ini menekankan bagaimana cara bertindak para pegawai dalam melaksanakan perkerjaannya, menekankan kepada para pegawai bagaimana suatu perkerjaan dapat diselesaikan dengan tepat pada waktunya dengan sedikit kemungkinan kekeliruan.

\section{Inisiatif (Initiative)}

Kemampuan untuk bertindak tidak tergantung pada orang lain, pengembangan serangkaian kegiatan dan menemukan caracara baru yang bersifat disoveri maupun inovasi dan dalam memperbesar tanggung jawab dibebankan kepadanya dengan sebaikbaiknya serta berani menghadapi resiko atas keputusan yang diambilnya.

\section{Kemampuan (Capability)}

Seseorang pegawai untuk berkerjasama dengan orang lain dalam menyelesaikan suatu tugas yang telah ditentukan sehingga mencapai daya guna dan hasil guna yang maksimal. Kesediaan pegawai dalam berpartisipasi dan berkerjasama dengan orang lain baik secara vertical maupun secara horizontal, didalam maupun diluar aktivitas kerja sehingga hasil perkerjaan akan meningkat.

\section{Komunikasi (communication).}

Alat yang digunakan untuk berkomunikasi, terutama dalam suatu sistem penyampaian dan penerimaan berita. Dalam suatu organisasi komunikasi sangat berperan dalam pencapaian tujuan karena tanpa adanya komunikasi, organisasi tersebut tidak akan berkembang.

Menurut Bono dan Judge (2003:4) mengukur kinerja dari banyak aspek. Terdapat tujuh kriteria yang dapat digunakan untuk mengukur kinerja karyawan secara individu yakni: (1) kualitas, yaitu hasil pekerjaan yang dilakukan mendekati sempurna atau memenuhi tujuan yang diharapkan dari pekerjaan tersebut, (2) produktifitas, yaitu jumlah yang dihasilkan atau jumlah aktivitas yang dapat diselesaikan, (3) ketepatan waktu, yaitu dapat menyelesaikan pada waktu yang telah ditetapkan serta memaksimalkan waktu yang tersedia untuk aktivitas yang lain, (4) efektivitas, adalah pemanfaatan secara maksimal sumber daya yang ada pada organisasi untuk meningkatkan keuntungan dan mengurangi kerugian, (5) kemandirian, yaitu dapat melaksanakan kerja tanpa bantuan gursa menghindari hasil yang merugikan, (6) 
komitmen kerja, yaitu komitmen kerja antara karyawan dengan organisasinya dan (7) tanggung jawab karyawan terhadap organisasinya. Tiga diantaranya yang dibahas dalam buku ini dipaparkan oleh Bono dan Judge (2003:5) sebagai berikut :

1) Kualitas Kerja, yaitu hasil pekerjaan yang dilakukan mendekati sempurna atau memenuhi tujuan yang diharapkan dari pekerjaan tersebut. Pengukuran kualitas kerja adalah sebagai berikut: karyawan memiliki kecermatan/ketelitian pekerjaannya, karyawan mematuhi prosedur operasional sesuai ketentuan organisasi, serta karyawan memperhatikan kebutuhan pelanggan yang dilayani.

2) Produktivitas, yaitu jumlah yang dihasilkan atau jumlah aktivitas yang dapat diselesaikan. Pengukuran produktivitas adalah sebagai berikut: karyawan mampu menyelesaikan tugas kerja yang diberikan sesuai target yang diberikan oleh organisasi, karyawan menggunakan waktu kerja dengan seksama, serta karyawan mampu menyelesaikan pekerjaan sesuai target yang diberikan organisasi ini.

3) Tanggung jawab, yaitu tanggung jawab karyawan terhadap organisasinya (organisasi). Pengukuran tanggung jawab adalah sebagai berikut: karyawan mampu hadir secara rutin dan tepat waktu di organisasi, karyawan mampu mengikuti instruksi-instruksi yang diberikan oleh organisasi ini, serta karyawan mampu menyelesaikan tugas dan memenuhi tanggung jawab sesuai batas waktu yang ditentukan.

\section{METODE PENELITIAN}

Penelitian ini menggunakan pendekatan kualitatif, dengan Jenis penelitian deskriptif, penelitian dilakukan pada Kantor Desa Indrasari Kecamatan Martapura Kabupaten Banjar Provinsi Kalimantan Selatan. Adapun Teknik pengumpulan data yang digunakan dalam penelitian ini adalah Studi Kepustakaan, Observasi, Wawancara, Dokumentasi dan laporan penelitian yang relevan dijadikan acuan dalam penelitian ini.

Data primer, data yang diperoleh secara langsung dari sumber pihak pertama, penelitian ini mengarah pada informan dan keterangan mengenai kinerja pegawai kantor Desa Indrasari Keacamatan Martapura yang menjadi informan dalam penelitian ini ada 4 orang yang terdiri dari Kepala Desa, Sekertaris, Kasi kesejahtraan dan pelayanan, Kaur umum dan. Data sekunder adalah data yang diperoleh secara tidak langsung untuk mendukung penelitian, pada penelitian ini melalui dokumen atau catatan yang ada, serta tulisan karya ilmiah dari berbagai media, literatur, arsip-arsip resmi yang dapat mendukung kelengkapan penelitian yang senantiasa berkaitan dengan masalah.

Wawancara dilakukan untuk mengumpulkan data primer dari informan penelitian, teknik wawancara ini dibuat dengan mempersiapkan terlebih dahulu panduan wawancara yang berisi pokok-pokok pertanyaan terbuka yang diajukan kepada informan penelitian, yang kemudian mendapatkan jawaban-jawaban yang relevan dan mendukung atas permasalahan yang ada, dari jawaban tersebut dilaksanakan pencatatan sederhana yang kemudian diolah dan dianalisa.

Analisis data dalam penelitian ini adalah Reduksi data, Penyajian data, dan Pengambilan keputusan atau verifikasi; Data yang diperoleh akan dipilih dan disederhanakan untuk mengambil data yang pokok, kemudian kumpulan informasi tersusun yang memberikan kemungkinan adanya penarikan kesimpulan/pengambilan tindakan, dalam verifikasi meninjau ulang catatan dengan maksud data yang di peroleh valid atas masalah yang diangkat dalam penelitian.

\section{HASIL DAN PEMBAHASAN}

Kinerja pegawai pada kantor Desa Indrasari Kecamatan Martapura Kabupaten Banjar dilihat dari 5 (lima) aspek, yakni Kualitas Kerja (Quality of Work), Ketepatan Waktu (Prompness), Inisiatif (Initiative), Kemampuan (Capability), Komunikasi (Communication). 
Kinerja pegawai pada kantor Desa Indrasari Kecamatan Martapura Kabupaten Banjar dilihat dari aspek Kualitas Kerja ( Quality of Work)

Dari hasil wawancara mengenai kualitas kerja bahwa sebenarnya masih ada tugas-tugas rangkap yang dikerjakan pegawai dan tumpang tindih perkerjaan, pegawai yang seharusnya berkerja masih banyak yang bersantai, tupoksi yang seharusnya di miliki satu Kepala Seksi/Kasi, ternyata dijalankan oleh Kepala Seksi lain, dan peneliti menganalisa bahwa beban kerja yang dimiliki pegawai pada kantor Desa Indrasari Kecamatan Martapura tidak terbagi secara merata pada setiap pegawai, seperti yang telah diuraikan oleh ka Dina, bahwa masih banyak tugas-tugas rangkap yang dikerjakan dan banyak pegawai yang seharusnya berkerja pada kenyataannya masih banyak yang santai.

Jika kita telaah menggunakan teori menurut T.R Mitchell (1978:34) dalam Sedarmayanti (2001:51) mengenai aspek kinerja yang ada tentang kualitas kerja bahwa Kualitas Kerja adalah kontribusi pegawai terhadap organisasi yang dilihat dari hasil kerja pegawai dan ketelitian serta kecermatan dalam penyelesaian atau pelaksanaan tugas, tingkat komitmen terhadap penyelesaian tugas, dan Peningkatan / perbaikan mutu hasil kerja. Hal ini bisa kita ketahui bahwa terlihat adanya ketidak sesuaian atau belum optimalnya kualitas kerja pada kantor Desa Indrasari Kecamatan Martapura bila dibandingkan dengan teori yang ada.

Terlihat bahwa beberapa pegawai kantor Desa Indrasari belum memiliki komitmen/tanggung jawab terhadap penyelesaian perkerjaan seperti melemparkan perkerjaan dengan pegawai lain sehingga terjadinya tumpang tindih perkerjaan pada pegawai lain dan belum terlihat adanya perbaikan mutu dalam penyelesaian perkerjaan.

Berdasarkan hal itu kualitas kerja pada kantor Desa Indrasari Kecamatan Martapura Kabupaten Banjar masih belum optimal.
Menurut analisa peneliti bahwa hal tersebut terjadi dimungkinkan karena kurangnya pemahaman pegawai terhadap perkerjaan dan kurangnya bimbingan teknis, pelatihan-pelatihan serta penyuluhan yang dilakukan secara berkala, sehingga akan ada hal-hal yang mungkin akan disarankan agar mutu kualitas kerja pada kantor Desa Indrasari semakin membaik.

\section{Kinerja pegawai pada kantor Desa Indrasa- ri Kecamatan Martapura Kabupaten Ban- jar dilihat dari aspek Ketepatan Waktu (Prompness)}

Berdasarkan hasil wawancara dapat disimpulkan bahwa Ketepatan Waktu (Prompnees) pada kantor Desa Indrasari Kecamatan Martapura Kabupaten Banjar dikatakan bahwa pegawai dalam penyelesaian perkerjaan dengan cara menganalisa sebuah perkerjaan atau dengan cara membacanya agar mengurangi suatu kesalahan, belum ada keterlambatan dalam pengerjaan tugas, untuk perkerjaan yang menumpuk akan dibawa pulang untuk diselesaikan dirumah agar selesai pada waktunya, dan konsekuensi pada kantor Desa Indrasari belum ada.

Jika kita telaah menggunakan teori menurut T.R Mitchell (1978:34) dalam Sedarmayanti (2001:51) mengenai aspek kinerja yang ada tentang ketepatan waktu bahwa Ketepatan Waktu yang menekan bagaimana cara bertindak para pegawai dalam melaksanakan perkerjaannya, menekan kepada para pegawai bagaimana suatu perkerjaan dapat selesai tepat pada waktunya dengan sedikit kesalahan/kekeliruan.

Hal ini bisa kita ketahui bahwa masih terdapat ketidakseimbangan antara teori dan hasil wawancara tentang ketepatan waktu, bahwa seharusnya pegawai mampu menyelesaikan perkerjaan tepat pada waktunya (jam kerja), tapi karena adanya wabah yang sekarang ini (COVID-19) mengharuskan pegawai berkerja pada kantor desa hanya 2-3 jam yang mengakibatkan banyaknya perkerjaan yang menumpuk karena waktu yang tidak memungkinkan sehingga mengharuskan mere- 
ka untuk membawa pulang perkerjaannya untuk mengganti jam kerja kantor.

Berdasarkan hal itu untuk ketepatan waktu pada kantor Desa Indrasari sudah memenuhi standar dan sudah dapat dikatakan optimal, karena keadaan yang sekarang menjadikan ketepatan waktu pada kantor Desa Indrasari tidak sama persis dengan teori yang ada.

\section{Kinerja pegawai kantor Desa Indrasari Kecamatan Martapura Kabupaten Banjar dilihat dari aspek Inisiatif (Initiative)}

Jika kita telaah menggunakan teori menurut T.R Mitchell (1978:34) dalam Sedarmayanti (2001:51) mengenai aspek kinerja yang ada tentang inisiatif bahwa Inisiatif merupakan kemampuan untuk bertindak tidak bergantung pada orang lain, dapat mengembangkan serangkaian kegiatan dan menemukan cara-cara baru yang bersifat disoveri maupun inovasi, dapat bertanggung jawab dan berani menghadapi resiko atas keputusan yang telah diambil.

Dapat kita ketahui bahwa terdapat ketidakseimbangan antara teori dan hasil penelitian, pada kenyataannya masih banyak pegawai yang bergantung pada pegawai lainnya untuk menyelesaikan tugas, dan masih banyak pegawai yang tidak mau belajar atas ketidak bisaannya, serta banyaknya pegawai yang menyepelekan tanggung jawab atas penyelesaian perkerjaan. Hal tersebut dapat dikaitan dengan beberapa pendapat mengenai tidak adanya konsekuensi/hukuman atas pelanggaran aturan yang telah di tetapkan serta kurang terbukanya pimpinan dan bawahan (evaluasi kerja), dengan hal itu pegawai masih berani mengulangi kesalahan yang sama dalam berkerja.

Berdasarkan hal itu jika dilihat dari teori yang ada dapat disimpulkan bahwa Inisiatif pegawai pada kantor Desa Indrasari Kecamatan Martapura masih kurang baik, melihat dari hasil wawancara diatas dikatakan bahwa hanya $50 \%$ pegawai yang mampu berinisiatif dan masih banyak pegawai yang mengandalkan pegawai lainnya, tidak bertanggung jawab atas pekerjaan yang sudah diambil.

\section{Kinerja pegawai kantor Desa Indrasari Kecamatan Martapura Kabupaten Banjar dilihat dari Kemampuan (Capability)}

Berdasarkan hasil wawancara dapat disimpulkan bahwa kemampuan pegawai dalam berpartisipasi sudah sangat bagus dapat dilihat dari keaktif pegawai dalam berkerja, saling membatu dam mengemukakan ide untuk penyelesaian perkerjaan dan pegawai juga rata-rata sudah mampu mengerjakan perkerjaan dengan cepat dan tepat. Tetapi ada perbedaan pendapat yang dikemukakan oleh informan, dilihat dari tanggap pimpinan bahwa hubungan kerjasama masih di lakukan di luar jam kerja sedangkan menurut ibu Sutiyah, S.Pd dan kedua stafnya bahwa hungan kerjasama hanya di dalakukan sebatas di jam kantor saja.

Jika kita telaah menggunakan teori menurut T.R Mitchell (1978:34) dalam Sedarmayanti (2001:51) mengenai aspek kinerja yang ada tentang kemampuan bahwa kemampuan memiliki arti sebagai berikut, "Kemampuan yang dimaksud ialah kempuan pegawai untuk berkerjasama dengan orang lain dalam menyelesaikan suatu tugas yang telah ditentukan sehingga mencapai daya guna dan hasil guna yang maksimal". Maka dengan telaah teori tersebut terlihat sedikit perselisihan yang mana sebuah kerjasama seharusnya dilakukan hingga menghasilkan daya guna dan tepat guna, pada kenyataannya pegawai hanya bisa berkerjasama pada lingkup/jam kantor saja, selepas dari jam kantor pegawai sudah sibuk masing-masing.

Namun hal tersebut bisa dikatakan sudah memenuhi standar atau sudah dapat dikatan optimal, karena mengingat keadaan (adanya COVID-19) ini mengakibatkan adanya perubahan jam kerja. Pegawai Indrasari yang seharusnya berkerjasama selama 8-9 jam kini berubah menjadi 2-3 jam saja, hal tersebut sangat berpengaruh terhadap penyelesaian 
perkerjaan yang berakibat pada kualitas kinerja pegawai.

Kemungkinan-kemungkinan lain yang bisa terjadi, menurut analisa peneliti dimungkinkan kurangnya bersosialisasi antar pegawai menjadikan kurangnya informasi antar pegawai, sehingga maksud dan tujuan antar pimpinan dan pegawai masih tidak sama, jika dilihat dari fakta lapangan berkerjasama dalam membantu masyarakat dalam hal pelayanan di luar jam kerja sudah tidak dilakukan, belum ada bukti bahwa suatu kerjasama masih dilakukan di luar jam kerja.

\section{Kinerja pegawai kantor Desa Indrasari Kecamatan Martapura Kabupaten Banjar dilihat dari aspek Komunikasi (Communi- cation)}

Berdasarkan hasil wawancara dengan informan mengenai aspek komunikasi pada kantor Desa Indrasari Kecamatan Martapura Kabupaten banjar bahwa kantor desa tersebut belum menggunakan sistem online (masih menggunakan surat) dalam pengiriman/penerimaan surat bahkan untuk pelayanan, waktu yang digunakan untuk pengiriman adalah sekitar 1 (satu) hingga 2 (dua) jam, karna menggunakan sistem manual permasalahan yang sering muncul ialah kesalahan pengetikan pada alamat yang di tuju/alamat tujuan.

Jika kita telaah menggunakan teori menurut T.R Mitchell (1978:34) dalam Sedarmayanti (2001:51) mengenai aspek kinerja yang ada tentang komunikasi, bahwa "Komunikasi yang dimaksud ialah alat yang digunakan untuk berkomunikasi, terutama pada sitem penyampaian dan penerimaan berita". Dengan telaah tersebut dapat kita ketahui bahwa kantor Desa Indrasari juga sudah menggunakan alat (surat sebagai penyampaian dan pengiriman informasi), itu artinya sudah memenuhi standar berdasarkan teori komunikasi yang ada. Namun, setelah peneliti dalami ternyata ada permasalahan yang sangat menganggu yaitu seringnya kesalahan pengetikan alamat tujuan.
Seringnya kesalahan pengetikan alamat tujuan dapat dianalisa bahwa dimungkinkan kurangnya ketelitian pegawai dalam berkerja, sedangkan hasil wawancara diatas dikatakan bahwa pegawai mampu berkerja dengan baik dengan cara ketelitian dan kecermatan dan pegawai telah memahami terlebih dahulu prosedur penyelesaian dalam setiap tugas. Berdasarkan hal itu hasil wawancara mengenai komunikasi kantor Desa Indrasari bahwa komunikasi yang dilakukan belum optimal, mengingat satu kesalahan yang sangat mengganggu kualitas kinerja lainnya, masih perlu adanya perbaikan-perbaikan yang seharusnya segera di perbaiki.

\section{KESIMPULAN}

Berdasarkan pembahasan diatas bahwa kinerja pegawai pada kantor Desa Indrasari Kecamatan Martapura Kabupaten Banjar sudah berjalan dengan baik walau masih terdapat kekurangan. Mengenai ketepatan waktu diatas bahwa kantor Desa Indrasari sudah memenuhi standar dan sudah dapat dikatakan optimal dalam aspek ketepatan waktu, dikatakan optimal karena keadaan yang sekarang (adanya COVID-19) menjadikan ketepatan waktu pada kantor Desa Indrasari tidak sama persis dengan teori yang ada, dalam keadaan yang sekarang untuk menyelesaikan perkerjaan hanya diberikan waktu 2-3 jam saja, sehingga banyak perkerjaan yang dibawa pulang atau dilanjutkan pada jam kerja besoknya, menyebabkan beberapa perkerjaan tidak terselesaikan tepat pada waktunya, Mengenai Inisiatif pegawai pada kantor Desa Indrasari Kecamatan Martapura Kabupaten Banjar masih kurang baik, karena disimpulkan bahwa hanya sebagian atau $50 \%$ pegawai yang mampu berinisiatif dalam penyelesaian perkerjaan dan masih banyak pegawai yang mengandalkan pegawai lain dalam penyelesaian tugas yang telah diberkan, dan juga tidak bertanggung jawab atas perkerjaan yang sudah diambil.

Dan aspek kemampuan pegawai pada kantor Desa Indrasari Kecamatan Martapura Kabupaten Banjar dapat dikatakan optimal dan sudah memenuhi standar teori yang ada. kare- 
na mengingat keadaan (adanya COVID-19) ini mengakibatkan adanya perubahan jam kerja. Pegawai kantor Desa Indrasari yang seharusnya berkerjasama selama 7-8 jam kini berubah menjadi 2-3 jam saja, hal tersebut sangat berpengaruh terhadap kerjasama dan partisipasi dalam penyelesaian perkerjaan yang berakibat pada kualitas kinerja pegawai.

Serta mengenai aspek komunikasi, kantor Desa Indrasari dalam berkomunikasi masih secara manual dengan menggunakan suratmenyurat, yang menyebabkan belum optimalnya sebuah komunikasi pada kantor Desa Indrasari ialah permasalahan yang menganggu kualitas kinerja lainnya, seperti sering terjadi kesalahan pengetikan alamat tujuan, jadi kesimpulannya masih terdapat beberapa pegawai dalam berkerja masih belum menggunakan ketelitian dan kecermatan seperti yang diungkapkan pada aspek lainnya.

\section{REFERENSI}

Abdullah Ma'ruf, SH.MM. 2014. Menejemen dan Evaluasi Kinerja Karyawan: Yogyakarta.

Dharma, Surya. 2012. Menejemen Kinerja Falsafah Teori dan Penerapannya. Yogyakarta: Pustaka Pelajar.

Dr. Indrasari, Meithiana, S.T, MM. 2017. Kepuasan Kerjadan Kinerja Karyawan. Sidoarjo: Indomedia Pustaka.

Hery, S.E,. M.Si,. CRP., CFRM., CIISA. 2019. Manajemen Kinerja. Jakarta: Grasindo.

Kadir, Abdul. 2015. Teori Kinerja dan Pengukurannya. Jakarta: Bumi Aksara.

Sinabela, Lijan Poltak. 2012. Teori Pengukuran dan Implikasi Kinerja pegawai. Jakarta: Graha Ilmu.

Sudarmayanti. 2001.Sumber Daya Manusia dan Produktifitas Kerja. Bandung: Mandar Manju. Cetakan ke II.

Sudaryanti. 2010. Kinerja dalam Matematika. Yogyakarta: Graha Ilmu. 